\title{
Animism: A Grassroots Response to Socioenvironmental Crisis in Japan
}

\author{
Shoko Yoneyama
}

\section{Introduction}

Socioenvironmental crises, such as global warming and nuclear disaster, indicate that modern industrial civilisation contains in itself a seed of self-destruction. While awareness of these problems is widespread, the problems themselves are so deeply imbedded in our civilisation that trying to find solutions within existing paradigms is almost a contradiction in terms. The knowledge base of the social scientific community, too, is formed around paradigms that seem incapable of addressing the fundamental crisis faced by contemporary civilisation. In this context, the discussion that follows examines two socioenvironmental catastrophes in contemporary Japan-Minamata disease and the triple disaster of 11 March 2011 (or 3.11) - from the perspectives of the local residents. I argue that animism has (re)emerged as a grassroots response to the two historical disasters in postmodernising Japan. ${ }^{1}$

\footnotetext{
1 This chapter, by permission, draws on and develops my article that appeared in 'Life-world: Beyond Fukushima and Minamata', in The Asia-Pacific Journal: Japan Focus 10, issue 42, no. 2 (2012) apjjf.org/2012/10/42/Shoko-YONEYAMA/3845/article.html and in Asian Perspective 37, no. 4 (2013). The inspiration to connect modernity, animism and Minamata came from the work of sociologist Tsurumi Kazuko (1918-2006). In particular, Tsurumi Kazuko Mandara VI: Tamashii no maki - Minamata, animizumu, ekorojii [Tsurumi Kazuko Mandala Volume VI: About the Soul Minamata, Animism and Ecology] (Tokyo: Fujiwara Shoten, 1998).
} 
Animism is defined here as an approach to life that presupposes the presence of a soul or spirit in animate and inanimate things in nature, covering all life (living, dead and yet to emerge), as well as other things such as water, air, soil, rocks, rivers and mountains. It is defined as a philosophy that allows the possibility of the presence of such things as soul or spirit, regardless of one's belief as to whether such an unseen world exists or not. My main concern here is to explore the relationship between modernity and the epistemology of animism, and its implications in considering the relationship between humans and nature in the world risk society - a world where life has become organised around risk, and where risk itself is generated for political gain.

The chapter consists of four parts. First, Minamata and Fukushima (as the 'epicentre' of the triple disaster of 2011) are positioned in the historical context of postwar Japan. I argue that both disasters represent cases where the 'connectedness that supports life' was severed not only in the biological sphere, but also in the social sphere and that, as a corollary, the pursuit of 'connectedness' emerged as the legacy of both disasters. Second, I present a discussion of the philosophy of 'life-world' (inochi no sekai いのちの世 界) developed by Minamata fisherman Ogata Masato, whose critique of modernity is that its epistemology fails to address the question of the soul (tamashii 魂).

The third section covers what I refer to as 'the Ishimure Michiko phenomenon': a dramatic increase in recognition of and interest in the work of Minamata writer Ishimure Michiko since the mid-1990s. Positioning Ogata and Ishimure as 'twin advocates' from Minamata, I argue that the phenomenon reflects a significant social change in Japanese society, i.e. the steady rise in post-materialistic values and increasing reflection on the limits of modernity. I argue that the Minamata discourse of animism, presented by Ishimure, addresses the needs of Japanese society as it matures into a postmodern society, especially after 3.11 when people became particularly interested in the relationship between humans and nature, or more precisely, in the question of life, nature and soul.

After exploring the animistic discourse from Minamata and the increased interest that it evokes, I introduce three examples where animistic tradition became a powerful resource for reconstructing communities in the disaster-stricken areas of Japan after the 3.11 triple disaster. They are: the case of folk festivals, the meaning of shrines as tsunami marker, 
and the significance of sacred forests (chinju-no-mori 鎮守の森). I argue that animistic epistemology, an intangible cultural heritage of Japan, was a common thread in grassroots responses to the triple disaster.

The conclusion of the chapter is this: in order to face the self-destructive tendencies of modernity, the philosophy of animism, reframed as an informal, grassroots life philosophy in post-industrial and post-3.11 Japan, opens up a new theoretical space to discuss relationships between humans, nature, and the unseen world. The grassroots responses to world risk society in Japan illuminate a lacuna in current Western-made social science: its inadequacy in fully addressing the questions of nature, spirituality, and life.

\section{Minamata, Fukushima and Connectedness: A Lacuna in Modernity}

German sociologist Ulrich Beck stated that Japan plunged into the 'world risk society' as a result of the nuclear accident in Fukushima. ${ }^{2}$ Beck's phrase 'world risk society' refers particularly to things such as nuclear accidents and global warming, unfortunate and unwanted byproducts of modernity, which threaten the very existence of our civilisation. In order to minimise the risk, Beck postulates that it is essential to transform the system itself-but the question is what to change and how to change it.

World risk society occurs in what sociologists call late, ${ }^{3}$ second, ${ }^{4}$ or liquid $^{5}$ modernity, the main characteristic of which is individualisation, where the connection between the individual and social institutions weakens. The moral and ethical foundations of society are also eroded. This raises the question of what moral and ethical foundation could be used to protect modern societies from the self-destructive tendencies of modernity. One reference we can draw on for considering this question is a report produced by the Ethics Committee for a Safe Energy Supply

2 Ulrich Beck, 'Kono kikai ni-Fukushima aruiwa sekai risuku ni okeru Nihon no mirai' [On This Occasion-Fukushima or the Future of Japan in World Risk Society], in Ulrich Beck, Suzuki Munenori, and Ito Midori eds, Risuku ka suru Nihon shakai [Japanese Society That Becomes a Risk] (Tokyo: Iwanami, 2011).

3 Anthony Giddens, Modernity and Self-Identity: Self and Society in the Late Modern Age (Stanford: Stanford University Press, 1991).

4 Ulrich Beck, World Risk Society (Cambridge: Polity, 1999).

5 Zygmunt Bauman, Liquid Modernity (Cambridge and Malden: Polity Press, 2000). 
in Germany, of which Beck was a member, in response to the Fukushima nuclear accident. Based on the report, Germany decided to decommission all its nuclear plants within 10 years. The report reads: 'A special human duty towards nature has resulted from Christian tradition and European culture. ${ }^{6}$ This begs an immediate question of what might be an Asian principle of environmental ethics.

When I think about the nuclear disaster in Fukushima from this perspective what puzzles me most is this: the 'Minamata problem' was studied by some of the best and the most critical social scientists in Japan, to the extent that they established what is now called 'Minamata Studies' (Minamata-gaku 水俣学). My question is why, then, after all this study, were we unable to prevent Fukushima? The question is not just about power and political economy, but also about epistemology. Have we not missed something important that is the key to understanding Minamata and Fukushima?

Minamata disease, one of the worst cases of industrial pollution in human history, was caused by organic mercury contained in effluent from the Chisso chemical factory in Minamata. It was officially recognised in 1956, which also marked the beginning of Japan's high economic growth period. After the official recognition, however, neither Chisso nor local or national governments took adequate measures to reduce the discharge for 12 years. In those 12 years, the production of acetaldehyde, for which organic mercury was used as a catalyst, increased threefold, exacerbating the poisoning. ${ }^{7}$ The Japanese Government finally recognised organic mercury as the cause of the problem in 1968, the year when Japan became the second-largest economy in the world. Subsequently, the organic chemical industry lost its edge, superseded by the petrochemical industry. ${ }^{8}$

The human cost of the Minamata problem is immeasurable. While the extremely stringent criteria required for government recognition as a Minamata disease patient has limited official numbers to about 3,000 (mostly deceased), an additional 11,000 sufferers received a payout in 1995 , and another 65,000 or more people applied for 'relief measures'

6 Ethics Commission for a Safe Energy Supply, Germany's Energy Transition - a Collective Project for the Future (Berlin: Offices of the Ethics Commission on a Safe Energy Supply in the Federal Chancellery, Germany, 2011).

7 Harada Masazumi, 'Minamata Disease as a Social and Medical Problem', Japan Quarterly 25, no. 1 (1978).

8 Ui Jun, 'Minamata Disease', in Ui Jun ed., Industrial Pollution in Japan (Tokyo: United Nations University, 1992). 
in 2012 when the Japanese Government launched what they called the 'final' compensation scheme. ${ }^{9}$ Epidemiological studies by independent medical researchers conducted in the 2000s estimated that some two million people in the Minamata region are still affected by low-level methyl mercury exposure. ${ }^{10}$ In addition to the human cost, the devastating impact upon other lives, such as fish, cats, pigs, birds, and the ecosystem has been immeasurable. ${ }^{11}$

The nuclear accident in Fukushima, on the other hand, occurred only days after China officially displaced Japan as the world's second-largest economy. ${ }^{12}$ The human cost of the nuclear disaster in Fukushima is also immeasurable. As of 2015, four years after the accident, there are almost 120,000 'nuclear refugees', ${ }^{13}$ who are at high risk of 'nuclear-accidentrelated death' (genpatsu jiko kanrenshi 原発事故関連死). Within three years of the disaster, over 1,700 (mostly elderly) deaths were related to the accident. Seven hundred of these deaths occurred more than a year after the accident while in the same time period, in the two other prefectures devastated by the tsunami, the number of disaster-related deaths was less than $20 .{ }^{14}$ In addition, by February 2016, 116 cases of thyroid cancer among youth had been confirmed. ${ }^{15}$ Using the incidence rate of thyroid cancer in the general population, around four cases would have been expected. ${ }^{16}$ The cost to other life forms was also immeasurable. Almost 3,000 cows, 30,000 pigs and 600,000 chickens and unaccounted numbers of pets were left behind to starve to death in the nuclear exclusion zone. ${ }^{17}$ Within five months of the accident, over 3,400 farm animals were

9 'More Than 65,000 Apply for Relief for Minamata Disease', Asahi Shimbun (English Digital), 1 September 2012.

10 Shigeru Takaoka, 'Minamata kara Fukushima e no kyōkun' [Lessons from Minamata to Fukushima], Shinryō Kenkyū [Clinical Research] 470 (August 2011).

11 Ogata Masato, Chisso wa watashi de atta [Chisso Was I] (Fukuoka: Ashi Shobō, 2001).

12 Robert Guy, 'It's Official, China Is No.2', The Australian Financial Review, 15 February 2011.

13 Ganjoho [Cancer Information Service Japan], Fukushima kara kengai e no hinan jōkyō [The Current State of Evacuation from Fukushima to Other Prefectures] (2015), www.pref.fukushima. lg.jp/uploaded/attachment/117392.pdf. Accessed 1 June 2016.

14 'Shimbun Kyōkai Shō honshi "Genpatsujiko kanrenshi' kyanpēn”" [Newspaper Association Award to Fukushima Minpō for 'Nuclear Accident-related Death' Campaign], Fukushima Minpō, 14 September 2014.

15 'Gan kakutei hitori mashi 16-nin, 2-junme kodomo kōjōsengan chōsa' [Confirmed Cases of Cancer Increased by One to be 16 in the Second Survey of Thyroid among Youth], Fukushima Minpō, 16 February 2016.

16 Ganjoho [Cancer Information Service Japan], 'Graph Database Tyroid Incidence Age-Specific Rate for 2010', ganjoho.jp. Accessed 14 June 2015.

17 'Ushi 3-zen to, buta 3-man biki, genpatsu 20-kiro ken ni - gashi ka' [3,000 Cows and 30,000 Pigs in the 20 Kilometre Zone - Death by Starvation Suspected], Yomiuri Online, 19 April 2011. 
'euthanised'. ${ }^{18}$ Genetic and ecological impacts on other species, such as birds, butterflies, cicadas have also been reported. ${ }^{19}$ Although the nuclear disaster was triggered by the earthquake and tsunami, the official report of the National Diet of Japan judged that the accident at Tokyo Electric Company (TEPCO) Fukushima Daiichi Nuclear Plant was 'manmade' in that it resulted from 'the collusion between the government, the regulators and TEPCO, and the lack of governance by said parties. They effectively betrayed the nation's right to be safe from nuclear accidents'. ${ }^{20}$ (See also Chapter Six.)

Minamata and Fukushima thus symbolise the beginning and the end of the period of Japan's economic development and its trajectory of modernisation. Both signify catastrophic environmental and social disasters, the impact of which is still current. Between 1956 and 2011, social science research in Japan has contributed enormously to understanding the structural problems associated with modernity as symbolised by Minamata. As a result, even though they are 55 years apart, we can see that there are fundamental commonalities between Minamata and Fukushima. From the perspective of political economy, the commonalities include the fact that both problems were based on relentless pursuit of profit; collusive relationships between industry, governments, bureaucracy, and the media; marginalisation of critical scientists; manipulation of scientific data; discrimination against rural people; and destruction of the food production base. In other words, Fukushima confronted us with the reality that the structures that caused and exacerbated the Minamata problem have continued almost intact, despite the knowledge gained in social sciences, allowing more 'manmade' devastation to happen, this time making Japan a world risk society. Here we come back to the question again: have we not missed something important, the key to understanding Minamata and Fukushima? What kind of knowledge can contribute to bringing about a fundamental change in society to prevent similar disasters from happening again?

18 'Anrakushi shobun no kachiku 3,422’ [3,422 Farm Animals Euthanised], Fukushima Minpō, 31 August, 2011.

19 Atsuki Hiyama, Chiyo Nohara, Seira Kinjo, Wataru Taira, Shinichi Gima, Akira Tanahara and Joji M. Otaki, 'The Biological Impacts of the Fukushima Nuclear Accident on the Pale Grass Blue Butterfly', Scientific Reports 2 (2012). Timothy A. Mousseau and Anders P. Møller, 'Genetic and Ecological Studies of Animals in Chernobyl and Fukushima', Journal of Heredity 105, no. 5 (2014). 20 The National Diet of Japan, The Official Report of the Fukushima Nuclear Accident Independent Investigation Commission: Executive Summary (2012), 16. 


\section{Breakdown of Connectedness}

Seen from a different angle, the commonalities between Minamata and Fukushima can be summarised as a breakdown of connectedness at a multitude of levels: family (e.g. the impact of death or health impairment of a family member, loss of housing, land, and other possessions); work (e.g. loss of a job and livelihood); food production (farming and fishing); traditional and local ways of life; and the sense of connectedness with nature, past and future, ancestors and descendants. Both disasters caused deep schisms and paralysis in the affected communities depending on the residents' position vis-à-vis the company responsible for the disaster and how each person wanted to respond to the crisis-in the case of Fukushima, typically a mother wanting to move to a safer place with the children while her husband and in-laws stayed put, leading to 'nuclear divorce' (genpatsu rikon).

The breakdown of connectedness occurred not only in sociological spheres, but also in biological dimensions. In the case of Minamata disease, connectedness in the nervous system of the brain was severed. Mercury disrupts the growth of neurons in the brain, and this severing of connectedness of the nervous system was visually captured in a video by researchers from the University of Calgary. ${ }^{21}$ The effect is the same for organic mercury that causes Minamata disease. ${ }^{22}$ Radiation, on the other hand, destroys DNA and severs connectedness among cells. A photo of DNA taken from Ōuchi Hisashi, who died after being exposed to an excessive amount of radiation in a localised nuclear accident in Tokaimura in 1999, shows that his DNA was completely torn into pieces by radiation. As a result, his body lost the connectedness that is necessary to maintain life, i.e. lost the memory required to regenerate cells, eventually turning his body cells into a pulp. ${ }^{23}$ If one of the characteristics of modernity is the weakening of connectedness, Minamata and Fukushima epitomise it to its extreme. They show how industrial nationalism, the most efficient capitalist system in modernity, ended up destroying the very core of life itself.

21 F. L. Lorscheider et al., 'How Mercury Causes Brain Neuron Degeneration', 2013, www. youtube.com/watch?v=Z1RHWfJSo6w. Accessed 16 June 2015.

22 M. Aschner et al., 'Metallothionein Induction in Fetal Rat Brain and Neonatal Primary Astrocyte Cultures by in Utero Exposure to Elemental Mercury Vapor (Hg0)1', Brain Research 778, no. 1 (1997).

23 NHK TV Crew, A Slow Death: 83 Days of Radation Sickness (New York: Vertical, 2008). 
Is it any wonder then that words that mean connectedness emerged as a legacy of both Minamata and Fukushima? In the case of Minamata, the key word is moyai 舫い, which means tying boats together. For the Fukushima/triple disaster it is kizuna 絆, meaning bonds. It is clear that people in Japan felt the need for more connectedness with society after Fukushima. This has been captured by official statistics as well. A public opinion survey conducted in 2012 by the Cabinet Office shows that 80 per cent of over 6,000 respondents indicated that, after the 2011 disaster, they came to realise the importance of connectedness with society to a greater extent than they did earlier. ${ }^{24}$

Feeling a sense of connectedness with everything around us, that is spirituality in the broadest sense. ${ }^{25}$ In this sense, the legacy of Minamata and Fukushima, namely moyai (tying ships together) and kizuna (bonds), can be considered as a discourse of spirituality. In other words, the civil discourse of Minamata and Fukushima can be considered to be a discourse of spirituality.

\section{'Life-world': A Critique of Modernity from Minamata}

Minamata fisherman Ogata Masato (緒方正人) is the person who coined the term moyai (tying ships together) as the legacy of Minamata. ${ }^{26}$ His critique of modernity is extensive, ${ }^{27}$ but his most profound insight is that:

The Minamata disease incident has left a question that cannot be dealt with as a political issue. It is the biggest and most fundamental question, a question that cannot be transformed into a question of politics or institutions. That is the question of the soul (tamashii 魂). ${ }^{28}$

24 Cabinet Office of Japan, Shakai ishiki ni kansuru yoron chösa [Survey on the Perceptions of Society] (Tokyo: Naifukaku, 2012).

25 Marian De Souza et al., 'General Introduction', in M. de Souza et al. eds, International Handbook of Education for Spirituality, Care and Wellbeing (Dordrecht: Springer, 2009).

26 Ogata Masato, interview by author, digital recording, Minamata, 16 January 2012.

27 For details see Shoko Yoneyama, 'Life-World: Beyond Fukushima and Minamata', The AsiaPacific Journal: Japan Focus 10, issue 42, no. 2 (2012).

28 Ogata, Chisso, 67. 
Ogata says that we need a more substantive expression of what soul is. He writes:

I have been thinking lately how we can convey what soul is, and what we can say about the soul ... Previously I stated that it is another name for life, but in a way, I think it can also be called 'the stamp of humanity' (ningen no akashi 人間の証). Especially after the war, various things have been modernised and mechanised so they can be integrated into the systemsociety. This has devoured the soul, which is the basis for the connectedness among people, between humans and other living things, and between humans and the sea, rivers and mountains ... I think that the promise of being human is to sense life (inochi o kankaku suru 命を感覚する) and to manage life (inochi o tsukasadoru 命を司る). Human beings are that sort of life-existence (seimei sonzai 生命存在) and, essentially, we are never a mechanical or institutional existence (emphasis added). ${ }^{29}$

How can soul be 'another name for life' and at the same time 'the stamp of humanity'? Underlying this is Ogata's notion of 'system-society' (sisutemu shakai システム社会) and 'the life-world' (inochi no sekaiいのちの世界 or seimei sekai 生命世界), the two sides of our modern living. By 'systemsociety' Ogata means a composite of institutional (legal, economic, political and to some extent social) aspects of modern society, ${ }^{30}$ which have a tendency to mechanise and institutionalise humans. 'The lifeworld' on the other hand represents the world from which we as human beings have emerged as 'life-existence', the world to which we return after death, the world that enables us to connect to other people, other forms of life and inanimate things in nature in a non-institutional way (i.e. simply as life) and the world that enables us to see the problems of systemsociety. ${ }^{31}$ By saying that soul is another name for life, Ogata poses soul as the essence of life, the essence of our existence, or the stamp of humanity that enables us to feel and manage life in such a way as to prevent us from being completely mechanised and institutionalised in the system-society, and perhaps, if we use the terminology of Beck, prevent us from being destroyed in the world risk society. Ogata's notion of the life-world thus refers to the entirety of life-soul-nature nexus that defies modernity.

29 ibid., 192-3.

30 ibid.

31 Yoneyama, 'Life-World'. 
What connects us to the life-world, in Ogata's philosophy, is the 'memory of life' (inochi no kioku 命の記憶). He writes:

In the age of 'modernity', we have standardised, institutionalised and mechanised many things in the name of modernisation. In the process, we reclaimed the sea of Minamata that was full of life saying that it was polluted by mercury. But perhaps it was not just the sea we buried. We have created a system of concealment to continue institutional and mechanical burying. That can be summarised as the creation of a 'false memory system' (偽りの記憶装置). By doing so, we have perhaps moved away from the essence of life, and the memory of the essence of life. I cannot help but feel that various social problems we face today happened because we have lost the 'memory of life' (命の記憶). ${ }^{32}$

For Ogata, 'memory of life' first means his own memory of the life he had as a child in a Minamata unpolluted by organic mercury, a memory also shared by other locals:

Once Minamata Bay was the treasure chest of our sea. Here schools of fish came to spawn. The young fry matured here and then returned to repeat the cycle. The bay was like a womb. In what is now landfill between Hyakken Port and Myojin Point, the silver scales of sardine and gizzard shad shimmered in the sunlight. Mullet leapt. Shrimp and crab frolicked in the shallow. At low tide we collected shellfish. At the edge of the waves we gathered seaweed - wakame and hijiki. These were the things that nourished us. ${ }^{33}$

This memory of life, where everyday living was almost entirely supported by the blessings of nature, was at one with the notion of gotagai, a word from the local Minamata dialect that means 'we're all in this together'. It is a name given to the sense of connectedness of all life within nature. Ogata writes:

[Gotagai] doesn't mean simply that we humans rely upon each other for our existence but that plants and animals are also partners in this life. Gotagai includes the sea, the mountains, everything. Human beings are part of the circle of gotagai; we owe our existence to the vast web of interrelationships that constitute life..$^{34}$

32 Ogata, Chisso, 63.

33 Oiwa Keibo and Ogata Masato, Rowing the Eternal Sea: The Story of a Minamata Fisherman, trans. Karen Colligan-Taylor (New York: Rowman \& Littlefield, 2001), 122.

34 ibid., 164. 
This 'web of interrelationships that constitute life' goes beyond his personal life. It also refers to the vast continuum of life, millions of years in the past as well as in the future. It is best portrayed by 'The Image of Biohistory', an artwork developed by the Osaka-based Biohistory Research Hall, which illustrates the history and diversity of life that came into being from a common genome over the course of 3.8 billion years. ${ }^{35}$ Biologist Nakamura Keiko, who was invited to the 50th Anniversary of the Official Recognition of Minamata Disease, stated that all living things share the same origin (genome); that human beings are only one of the diverse species that share the same history of development; and that human beings are in nature (i.e. not outside it). In her speech she stressed the importance of regaining our sense of being as living things (ikimono to shite no kankaku o torimodosu生き物としての感覚をとりもどす). ${ }^{36}$

'Regaining our sense of being as living things' was also the main point of Ogata's keynote speech at the conference. The aim of the conference was to present recommendations from Minamata to the world about how to achieve a sustainable future, transcending victimhood. The conference proceedings are titled 'Minamata for New Genesis: Recommendations for the Future' (Soseiki o Mukaeta Minamata: Mirai e no Teigen 創世記を 迎えた水俣: 未来への提言). ${ }^{37}$ Ogata concluded his keynote speech by saying that:

Although we live in the system-society where economy is based on insatiable wants and desires (yokubō keizai 欲望経済), I think that there will be a way to transcend it with a new meaning. A hint can be found in our sense of life as a living being (ikimono to shiteno inochi no kankaku 生き物としての命の感覚). For that, I think it is time for each of us to return to the starting point as one life-existence (seimei sonzai 生命存 在), from where we re-live a life ... The new 'genesis' (sosseiki 創世紀) included in the title of this conference, Minamata for New Genesis, is also sōseiki 創生紀, an era to create life. ${ }^{38}$

35 Nakamura Keiko, Dan Marina, and Hashimoto Ritsuko, 'The Image of Biohistory', JT Biohistory Research Hall, www.brh.co.jp/imgs/about/emaki/emaki.jpg. Accessed 20 June 2015. 36 Nakamura Keiko, 'Seimei kagaku: Ikimono kankaku de kangaeru' [Bioscience: To Think about it with Senses of a Living Creature], in Saitō Yasuhiro et al. eds, Söseiki o mukaeta Minamata: Mirai e no teigen [Minamata for New Genesis: Recommendations for the Future] (Minamata: Minamatabyō Kōshiki Kakunin 50-nen Jigyō Iinkai, 2007).

37 Ogata Masato, 'Keynote Speech: Sōseiki o mukaeta Minamata: Mirai e no teigen' [Minamata for New Genesis: Recommendations for the Future], in Minamatabyō Kōshiki Kakunin 50-nen Jigyō Jikkō Iinkai ed., Söseiki o mukaeta Minamata.

38 ibid., 31. 
More practically, though, Ogata asks 'how [can we] break ourselves from our own spell and liberate ourselves' 39 from the spell of 'system-society' driven by the pursuit of affluence? He does not suggest that we should give up living in system-society in order to pursue living in the life-world. Rather, he sees the relationship between the two as 'right foot and left foot': both indispensable for walking. The question is how to live within this potentially contradictory dual structure.

We need to think how to live with the dual structure. In the globalcapitalist-market economy, we are controlled by a view of the world dominated by the economy and we cannot escape from it. It is a world regulated by clock-time, and we feel as if everything is controlled by the overwhelming power of the economy and politics. But precisely because of this, I think it is necessary to have our own time in 'cosmic-time', in order to relax and refresh, and find and regain a sense of our true selves. I think that each person is like a small universe and that it is possible for each of us to find our own way, existentially, to connect to the cosmictime where life is eternal. It seems to me that living this duality provides a very important hint for us to remain and regulate ourselves as humans. To put it differently, we work in the system-society to earn our living, and we live in the life-world to live our life. It's like doing two-sword fencing, or having two different, top and bottom, streams of wind, or a double helix structure in one's life. ${ }^{40}$

For Ogata, to recognise this duality means understanding that he himself was part of the 'Chisso-ish' society and to recognise that he was 'another Chisso' in a sense that he is part of history where it is not possible to live without relying on materials and systems supported by companies like Chisso. Ogata emphasises, however, the importance of knowing where each of us 'stands', i.e. 'where you put your centre of gravity' (jüshin 重 心) and 'where you point your soul'.41

Sadly, I myself cannot escape from the money economy or the economic system. I use my mobile phone, and my boat is equipped with GPS, for instance. Although I cannot escape from the system, I am still resisting stubbornly. What is it that I am defying? There is only one point ultimately. It is where you put your 'trust' (shin o doko ni oku ka 信をどこに置くか, with shin as in shinrai 信頼). In the end, it is the question of where you place your trust, the system-society or the life-world. ${ }^{42}$

39 Ogata Masato, telephone interview by author, digital recording, Sydney to Minamata,

25 August 2012.

40 ibid.

41 ibid.

42 ibid. 
For Ogata, the life-world presents an absolute, ethical frame of reference in which he, as human being, has a responsibility to nature even though he is living in the system-society. What empowers humans to do this task, according to Ogata, is our soul, our memory of life, the life that makes us human, the stamp of humanity, i.e. the life-world as the life-soul-nature nexus that defies modernity. Ogata presents a philosophy, a foundation for environmental ethics that addresses human responsibility vis-à-vis nature/ life at this historical crossroad when the globalising world faces the lifethreatening reality of 'self-reflexive' modernity.

In the terminology of Morris-Suzuki, Ogata's philosophy of life-world is a voice of 'informal life politics' or 'survival politics' that arises from grassroots Japan. In the terminology of Lyotard, it is a little narrative that can produce a new kind of knowledge that opens up our imagination to the unknown, something that has been outside the epistemological boundaries of existing knowledge. ${ }^{43}$

The new space Ogata opens up is the space to address life (inochi 命), soul (tamashii 魂) and nature as a single mutually entwined relational entity. The concept of moyai (tying ships together), a legacy of Minamata, is part of this philosophy. His notion of the life-world is a strong critique of modernity in that it questions a key empirical reality of modernity. He argues that modernity 'devours the soul' from everyday life and 'despiritualises' cultures. ${ }^{44} \mathrm{He}$ also challenges modernist epistemology: the secularist premise of social science that puts matters related to spirituality (or the unseen world) outside its boundary. Although Ogata himself does not use the word animism, his philosophy of life-world is a contemporary version of animism 'armed' with deep insights into modernity. And it is precisely the issues of animism that have been treated in sociology 'with the utmost reserve, if not disdain', ${ }^{45}$ as if it was 'magic'. The elimination of 'magic', according to Max Weber, is 'one of the most important aspects of the broader process of rationalisation', ${ }^{46}$ that is to say, it is the key to modernity.

43 J. F. Lyotard, The Postmodern Condition (Minneapolis: University of Minnesota Press, 1979), 60-7.

44 Kieran Flanagan, 'Introduction', in K. Flanagan and P. Jupp eds, A Sociology of Spirituality

(Farnham: Ashgate, 2007), 1.

45 ibid.

46 Talcott Parsons, 'Translator's Note (Chapter IV, Endnote 19)', in The Protestant Ethic and the Spirit of Capitalism by Max Weber (London: Unwin University Books, 1930-1974), 222. 
Lyotard defines postmodern as 'incredulity towards the metanarrative' ${ }^{\text {' }}$ of modernity, and the principle of postmodern knowledge to be 'not the expert's homology, but the inventor's paralogy'. ${ }^{48}$ In that sense, the lifeworld is postmodern knowledge or, more precisely, a postmodern version of animism that emerged as a grassroots response to the socioenvironmental disaster that hit a periphery of Japan at the height of its industrialisation. While Ogata illuminates and articulates the relationship between the system-society and the life-world in lucid and powerful language, the sociological significance of his work is better understood in conjunction with the works of the writer Ishimure Michiko, in the context of what I call the 'Ishimure Michiko phenomenon'.

\section{The Ishimure Michiko Phenomenon: An Animistic World to Pine for}

Ishimure Michiko (石牟礼道子) is a Minamata writer, often referred to as an environmental novelist, or the Rachel Carson of Japan, and is one of the key members of the Minamata movement. Her signature piece, Kugai Jódo: Waga Minamata Byo [Paradise in the Sea of Sorrow: My Minamata Disease 苦海浄土わが水俣病] illustrates the plight as well as the beauty of life of those affected by the disease/poisoning, in a novel that is based on factual information about Minamata. Like Ogata, Ishimure's work is fundamentally a critique of modernity, and like him, life, soul and nature are at the core of her work. ${ }^{49}$ Unlike Ogata, however, Ishimure uses the term 'animism' whereas Ogata, as mentioned earlier, uses the phrase life-world. Ishimure writes:

With what sort of human character should we describe the immoral behaviour of the modern industry that exacted and continues to exact harm to nature and to the very basis of life therein, in the remote villages of Minamata? It surely was another form of the ruthless exploitation of people and nature by monopolistic capitalism. Yet, simply to point that out will not be sufficient. Living spirits and dead spirits hover over my hometown without being able to attain Buddhahood. I consider

47 Lyotard, Postmodern, xxiv.

48 ibid., xxv.

49 Ishimure Michiko, Ishimure Michiko zenshü [Complete Works of Ishimure Michiko] (Tokyo: Fujiwara Shoten, 2004-2014). 
the words of these spirits as the pristine language of their social class. I therefore must become a shaman for modernity by fusing my notion of animism and pre-animism. ${ }^{50}$

Although Ishimure does not use the word animism often in her literary work, an animistic ambiance runs through her work, in her descriptions of nature and people. The one closest to the definition of animism is the following passage from Kamigami no Mura [Villages of the Gods 神々 の村].

A communal village well almost always was located in a place where camellias and other evergreens grew thick. Trees would collect water for the spring and the spring in turn would nourish the trees. Time immemorial dwelled in the spring and in the trees.

Each well had its own kami (deity/god/spirit カミ); mountains had a kami; ships had a kami; rocks had a kami; rice paddies had a kami; sea had a kami; rivers had a kami; each kami dwelled in its own place and had a unique and lovable character.

The cheeky careless kami of the river, who had a plate attached to the top of its head, would go up the river, deep into the mountains, and sneak into, in the depth of the night, into a miner's hut at the Fuke Gold Mine in Satsuma ...

When people wanted to have a kami for their rice field, they would find a suitable stone, pour lots of shöchī (potato wine) onto it, and thus imbue a soul into the stone. The villages were protected by impromptu kami such as these. The little kami in fact were also the people themselves. ${ }^{51}$ (Author's translation)

Although Paradise in the Sea of Sorrow was published in 1969, Ishimure was marginalised for a long time as a literary figure, until the $1990 \mathrm{~s}^{52}$ Since then, there has been a substantial increase of recognition and interest in her work in Japan, which then created a snowball effect and what might be called the 'Ishimure Michiko phenomenon' occurred. The change is

50 Ishimure Michiko, Kukai jōdo sekai bungaku zenshū III-04 [Paradise in the Sea of Sorrow, World Literature Series III-04] (Tokyo: Kawade Shobō, 2011-2012), 44.

51 ibid., 236.

52 Watanabe Kyōji, 'Ishimure Michiko no jiko keisei' [The Establishment of Self of Ishimure Michiko], in Iwaoka Nakamasa ed., Ishimure Michiko no sekai [The World of Ishimure Michiko] (Fukuoka: Gen Shobō, 2006). 
indicated clearly by the number of times her name appeared in the Asahi newspaper as shown in Figure 4. (This data was collected using the Kikuzo II database of both eastern and western Japan versions of the Asahi).

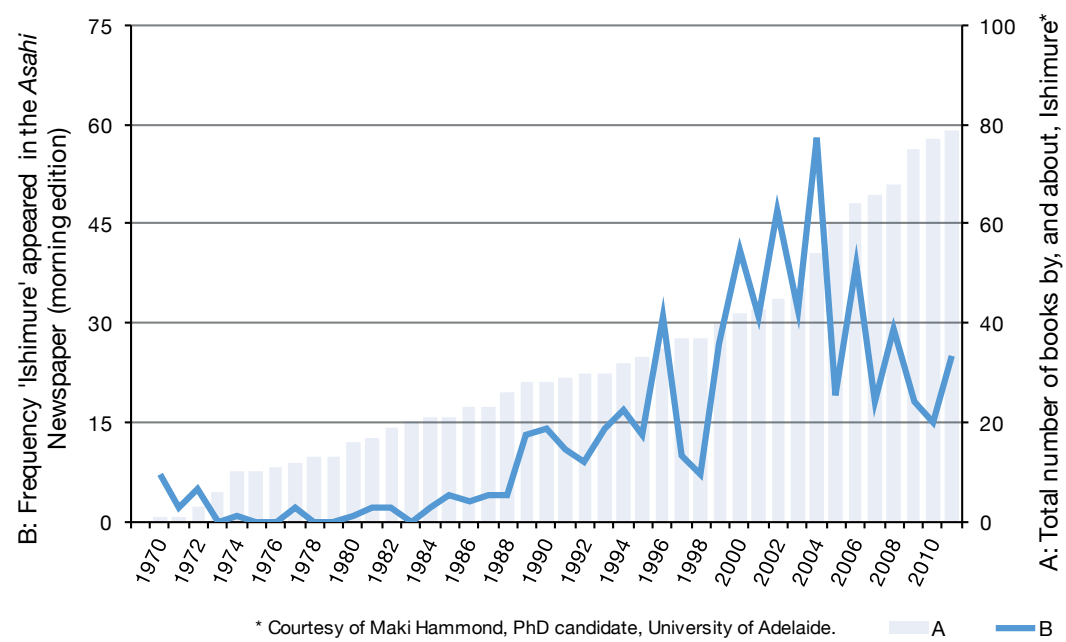

Figure 4: The 'Ishimure Michiko Phenomenon': Ishimure Michiko in the mainstream media (1970-2014).

Source: Author's work.

Another strong indicator of the Ishimure phenomenon is the succession of awards she has received since the 1990s. In 1993, she received the Murasaki Shikibu Literary Award, with commendations by Umehara Takeshi, the then Director of the International Research Center for Japanese Studies, and Setouchi Jakushō, a renowned writer. This award connected Ishimure for the first time officially with the mainstream literary world of Japan. She then received a 2001 Asahi Award, together with Miyazaki Hayao and others; followed by a 2002 Minister of Education and Science Award for the Promotion of Art; 2013 Avon Award for Women; and, in 2014, the 32rd Hanatsubaki Award for Contemporary Poetry by Shiseido and the prestigious 8th Gotō Shinpei Award.

The recognition of Ishimure's work took different forms as well. Her longterm friendship with sociologist Tsurumi Kazuko, a grandchild of Meiji statesman Gotō Shinpei, led to a chance to talk in length with Empress Michiko at Tsurumi's memorial service, which subsequently led to a visit by the Heisei Emperor and Empress to Minamata in 2013. For the first 
time in history after the outbreak of Minamata disease in the 1950s, a Japanese emperor visited Minamata, and following Ishimure's request, the royal couple met congenital Minamata disease sufferers who were in their 50s. ${ }^{53}$ The Asahi newspaper twice reported the role Ishimure played in the royal visit, in such a way that generated a sense of reconciliation and healing between Minamata sufferers and the imperial family. ${ }^{54}$

There seem to be three intertwined factors behind the Ishimure Michiko phenomenon. First is the steady publication of her highly original work. ${ }^{55}$ In addition to literary works, Ishimure produced numerous collections of poems, picture books and essays, including a column in the Asahi newspaper, Chotto Shinkokyū [Taking a Big Breath] that lasted from 1999 to 2005.

The second factor explaining the Ishimure Michiko phenomenon is the development of the Minamata movement itself, in which Ogata and Ishimure have been key players. The first big spike in Figure 4 coincides with the 1996 Minamata Tokyo Exhibition that was held to mark the 40 th anniversary of the official recognition of Minamata disease. One of the key features of the exhibition was an old, barely seaworthy fishing sailboat, the Nichigetsu maru [Sun Moon Boat 日月丸], which Ogata sailed from Minamata to Tokyo in order to push the poison back to the capital'. ${ }^{56}$ This exhibition heralded a new era whereby Minamata became connected at a new level to the civil society of Japan. For instance, Minamata Forum, a Tokyo-based non-profit organisation that organised the Tokyo Exhibition, has continued to show the exhibition at 23 other venues since the original event in 1993, attracting over 130,000 visitors

53 Kitano Ryūichi, "Ima mo kurushimu Minamata no kanja ni atte” - Ishimure-san kōgō-sama ni tegami' [Please Meet Still Suffering Minamata Patients - Ishimure Wrote a Letter to the Empress], Asahi Shimbun, 25 October 2013, Tokyo.

54 Kitano Ryūichi, 'Ishimure-san ga miokuri - Kōgō-sama kara dengon "Okarada taisetsu ni”'[Ishimure Saw Them Off - a Message from the Empress - Please Take Care], Asahi Shimbun (Seibu), 29 October 2013.

55 This includes compilations of her work: an 18-volume Ishimure Michiko zenshü [Complete Works of Ishimure Michiko] published by Fujiwara Shoten between 2004 to 2014; and another series, a seven-volume Ishimure Michiko shibun korekushon [Ishimure Michiko Literary Works] published also by Fujiwara in 2009 and 2010. In 2011, just before the triple disaster, Ishimure's flagship work, Kukai jōdo (Trilogy), was published as part of Sekai bungaku zenshū [World Literature Series], as the only Japanese entry in the series. The trilogy included 1969 Kugai jödo [Paradise in the Sea of Sorrow], 1997 Tenko [Lake of Heaven] and 2006 Kamigami no mura [Villages of the Gods], which altogether took 40 years to complete.

56 Ogata, Chisso, 122. 
by $2015 .{ }^{57}$ In May 2016, a special memorial lecture series to mark the 60th anniversary of the official recognition of Minamata disease, held by the Minamata Forum at the University of Tokyo, was attended by nearly 2,400 people including some 90 volunteers..$^{58}$

At the same time, key players of the Minamata movement began to express themselves in different ways. Ogata's two books were published in 1996 and 2001, the latter being Chisso was I. ${ }^{59}$ Ishimure's Noh play was performed in Tokyo, Kumamoto and Minamata in the early 2000s. The 50th anniversary of the official recognition of Minamata disease was titled 'Minamata for New Genesis', reframing the Minamata incident as a historical experience with a significant message for the future. A field of study, Minamata Studies, was established in the 2000s by Harada Masazumi, a doctor who had devoted his entire working life to the care of Minamata disease patients. Kumamoto Gakuen University where Harada taught became the mecca of Minamata Studies and the five-volume Minamata Gaku Kögi [The Minamata Studies Lectures 水俣学講義] was published between 2004 and 2012. The Minamata incident has thus entered a new phase since the mid-1990s and has flourished. In Ogata's words, Minamata is no longer a 'movement' but an 'expression'. ${ }^{60}$ Through these developments since the mid-1990s, Minamata disease has become established as a robust reference point of civil society Japan. The work of Ishimure Michiko has been the key medium to connect Minamata and civil society, and the Ishimure Michiko phenomenon is an indication of the strength of that connectedness.

The third factor behind the Ishimure Michiko phenomenon is a broader social change in Japanese society. ${ }^{61}$ World Values Surveys show that 'postmaterialist values' are one of the strongest indicators of the cultural

57 Minamata Forum, 'Minamata Forum katsudō naiyō' [Minamata Forum Activities], www.minamata-f.com/activity.html. Accessed 29 June 2013.

58 Minamata Forum, Minamata-byō kōshiki kakunin 60nen kinen tokubetsu kōenkai [Special Memorial Lecture Series to Mark the 60th Anniversary of the Official Recognition of Minamata Disease], www.minamata-f.com/evt_201605.html. Accessed 2 July 2016.

59 Ogata Masato and Tsuji Shinichi, Tokoyo no fune o kogite [Rowing the Eternal Sea] (Tokyo: Seori Shobō, 1996); Ogata, Chisso.

60 Ogata Masato, interview by author, digital recording, Minamata, 25 January 2013.

61 This paragraph first appeared in Shoko Yoneyama, 'Spirituality in Life Stories in Postmodernising Japan', Elizabeth Morrell and Michael Barr eds, Referred Conference Proceedings, the 18th Biennial Conference of the Asian Studies Association of Australia, ASAA (Adelaide: Asian Studies Association of Australia, 2010). 
transformation from modern to postmodern ${ }^{62}$ and that Japan was part of this major shift in the highly industrialised world. ${ }^{63}$ This value change has been captured in public opinion polls that are conducted annually by the Cabinet Office. In the early 1980s, the proportion of those who considered the 'richness of heart/mind' (kokoro no yotakasa 心の豊かさ) to be more important than 'material affluence' (mono no yutakasa 物の 豊かさ) exceeded those who valued the 'material' over the 'mind/heart', and the gap became wider, reaching 64 per cent for 'mind/heart' and 30.1 per cent for 'material' in 2012. ${ }^{64}$ For many people, the meaning of existence has become more important than what they possess. Japan has been very much part of the rise of a 'new spiritual culture' in industrialised societies, which surfaced in Japan as the rise of interest in 'mind/heart world'. ${ }^{65}$ The word supirichuaru (spiritual) became a buzzword in the 2000s, and played a pivotal role in the discourse of the new spirituality culture. A linguistic study of supirichuaritii (spirituality) as a loan word found that the word 'spirit' has been translated as tamashii (soul 魂), kokoro (heartこ ころ or 心), or inochi (life いのち or 命), suggesting the close relationship between the notions of 'soul' and 'life' in Japan. ${ }^{66}$

This broad value change that began in the 1980s has been amplified by a major shift in Japanese society since around 1990, which pushed people to reflect on the meaning of prosperity in a society that had reached its growth plateau. It started with the 1989 death of the Showwa Emperor, Hirohito, who symbolically represented the 'postwar' development. This was followed by the 1990 bubble burst, the collapse of an excessively speculative money economy based on the construction industry that was the mainstay of Japan's economy in the 1980s. At the time when Japan became a post-industrial society in 1995 and the labour force in the service industry exceeded that of manufacturing, Japanese society was awash with incidents that pushed its citizens to ask existential questions. These incidents included the Hanshin-Awaji Earthquake in Kobe, the

62 Ronald Inglehart, Modernization and Postmodernization (Princeton: Princeton University Press, 1997), 86.

63 ibid., 333.

64 Ministry of the Environment (Japan), Kankyō hakusho, junkangata shakai hakusho, seibutsu tayosei hakusho [White Paper on the Environment, Recycling Society and Bio-Diversity] (Tokyo: Ministry of the Environment, 2013), chapter 2, section 1, www.env.go.jp/policy/hakusyo/h25/html/ hj13010201.html. Accessed 2 July 2016.

65 Shimazono Susumu, Spirichuaritii no köryū [The Rise of Spirituality] (Tokyo: Iwanami Shoten, 2007).

66 Harumi Minagawa, “'Spiritual” Interpreted: A Case of Complex Lexical Borrowing in Japanese', Japanese Studies 32, no. 3 (2012). 
terrorist sarin-gas attack by the Aum Supreme Sect in the subway near the government district of Tokyo, and a series of horrendous crimes committed by youth, starting with the decapitation of a boy by a 14-year-old 'school killer' in Kobe. ${ }^{67}$ The level of anxiety in society was amplified by economic stagnation since the early 1990s, a major policy shift for casualisation of the workforce in 1995, and the spread of neoliberalism, which had broad implications (e.g. the prevalence of the culture of bullying in Japanese society in general). ${ }^{68}$

The Ishimure Michiko phenomenon occurred against this backdrop of growing scepticism about economic development, broader value changes in postindustrial and postmodern Japan, and increasing need to respond to existential questions. It was also in this context that people in Japan were confronted with the 3.11 triple disaster, and Ishimure was no exception. The nuclear accident in Fukushima in particular provoked her sense of mission, and raised the significance of her work to a new height. A documentary film on Ishimure Michiko, released in 2013, 'Hana no okudo e': Ishimure Michiko rasuto messēji [Towards the Paradise of Flowers: Ishimure Michiko's Last Message 花の憶土へ], opens with an introductory statement:

Ishimure Michiko has kept questioning the 'poison of modern civilisation'. In post-3.11 Japan, she extends her questions to the destiny of the Earth. ${ }^{69}$

Sociologist Mita Munesuke, Emeritus Professor of Tokyo University, captured the relevance of Ishimure's work as follows:

'Minamata Disease' represents nothing but the malady of Japan's capitalism as a whole. And if the collapse of the 'life-world' constitutes the malady of the modern world as a whole, the essence of Ishimure Michiko's work is that it provides spiritual medicine that heals the body and the soul of the modern world (My translation. Emphasis added.) ${ }^{70}$

67 Shoko Yoneyama, The Japanese High School: Silence and Resistance (London and New York: Routledge, 1999).

68 Shoko Yoneyama, 'The Era of Bullying: Japan under Neoliberalism', The Asia-Pacific Journal: Japan Focus 6, issue 2, 1 December (2008).

69 Kin Taii, Hana no okudo e [Towards the Paradise of Flowers] (documentary film), 2013.

70 Mita Munesuke, 'Ijutsu toshite no sakuhin: “Ten no Io” o yomu' [Literary Work as a Medical Art: Reading the Fish of Heaven], in Shiranui: Ishimure Michiko no kosumolojii [Shiranui: The Cosmology of Ishimure Michiko] (Tokyo: Fujiwara Shoten, 2004). 
The Ishimure Michiko phenomenon can be considered as an indication that Japanese society has been in need of 'spiritual medicine' as an antidote to modernity. She made this evident through her illustrations of the world where humans live as part of nature, as part of the continuum of life, or the life-world where life and 'soul' (tamashii) are connected. And this is the world that was destroyed by Chisso, a company that represented modernity and the domination of money and materials over life, soul and nature. In the context of Japan, the cultural reference that addresses the life-soul-nature nexus is animism. The Ishimure Michiko phenomenon suggests that even before the triple disaster, there was an increasing interest in the life-soul-nature nexus vis-à-vis modernity. As in the case of Ogata, Ishimure's work has provided a robust discourse on life-soul-nature, or discourse on animism as a grassroots response to the first socioenvironmental crisis in post-war Japan.

It is on the basis of this idea that I now turn to the final section of the chapter, which introduces three developments that suggest animistic tradition has regained relevance in post-3.11 Japan. The developments are renewed appreciation of folk festivals, local shrines, and sacred forests (chinju-no-mori) in the disaster-stricken areas.

\section{Reconnecting with the Cultural Heritage of Animism in Post-3.11 Japan}

Folk Festivals: Folklorist Akasaka Norio (赤坂憲雄), who specialises in Northeast Japan, points out that folk festivals/arts (minzoku geinō 民俗 芸能), though they had been in decline before the triple disaster, were the very first thing to be revived in many tsunami-struck communities. ${ }^{71}$ Akasaka introduces the case of the Deer Dance in Minamisanriku, which is particularly relevant here. Minamisanriku is in the area where the tsunami was most ferocious, and in this town alone more than 800 people, or one in 20 of the population, lost their lives. The whole town was reduced to rubble, and the community was decimated. How was it possible to reconstruct a local festival in such a situation? Akasaka writes about a local fisherman, Muraoka Kenichi, who lost everything and wandered through the rubble for months, searching for anything related to his life. He found only two things. One was a shell ring he had made for his wife, and

71 Akasaka Norio, 3.11 kara kangaeru 'kono kuni no katachi' [Post 3.11 Reflections on the Way We Are in This Country] (Tokyo: Shinchō Sensho, 2012), 85. 
the other was a taiko drum used in the traditional Deer Dance. ${ }^{72}$ Before the tsunami, Muraoka had played a key role in preserving the dance. He thought that the taiko would have been washed away, together with everything else, because of its light weight. When he found the drum in the mud, he thought: 'Okay, I might be able to start again'. ${ }^{73}$ Eventually, locals managed to find all but one of the drums along with costumes and outfits for the dance, all buried in the mud. The first person keen to do the Deer Dance was a 12-year-old boy, Onodera Shō, who persuaded his friends, who were scattered among various shelters, to learn the dance together. ${ }^{74}$ When the revived Deer Dance was finally performed, local people watched it with tears in their eyes. ${ }^{75}$

Akasaka remarks that folk festivals/arts played a significant role in uniting people in the disaster-stricken communities that were divided by numerous private differences: were there deaths in the family, were the bodies found or not, and was the family house lost, etc. Festivals were particularly effective in uniting people because acts of sacrament for the dead as well as repose for dead souls are strong themes of local festivals in Northeast Japan. Also, the festivals are open to everyone, unlike Buddhist funerals, which are strictly a family matter. ${ }^{76}$

Significantly, the dead souls in this context include those of animals. Concerning the Deer Dance, for instance, a memorial stone erected approximately 300 years ago reads: 'This dance is dedicated to the repose of the souls of all creatures living or dead'. ${ }^{77}$ In addition to the Deer Dance in Minamisanriku, there are various other versions of the dance as well as other animal-related festivals/arts in the region. Akasaka holds that animism is an intrinsic part of the festivals and is also associated with the Buddhist notion of shikkai jöbutsu (悉皆成仏). ${ }^{78}$ In Japanese Buddhism, shikkai jōbutsu, the long version of which is sansen sommoku shikkai jōbutsu (山川草木悉皆成仏), means universal enlightenment not only for humans but for all entities, living and dead (i.e. humans, animals, birds, insects, etc.), including grass and trees, as well as other

72 ibid., 84-5 and 154-5.

73 Ishino Nahoka, 'Furusato ni hibike, bokura no kodō to yakudō' [May Our Heart Beat and Our Energy Reverberate in Our Hometown], Kokoro Puresu [The Heart Press], 2014, kokoropress. blogspot.com.au/2014/01/blog-post_24.html. Accessed 2 July 2016.

74 ibid.

75 Akasaka, 3.11 kara, 155.

76 ibid.

77 ibid., 158.

78 ibid., 159. 
inanimate things such as mountains and rivers. To what extent people engaging in the recovery of folk festivals/arts were conscious of such cultural traditions is unknown. As pointed out by Akasaka, however, folk festivals/arts functioned as a latent cultural mechanism connecting people divided by the disaster. ${ }^{79}$

Shrines as Tsunami Markers: Imamura Fumihiko (今村文彦), a specialist in tsunami engineering and disaster archives, presents a picture of a tiny wooden shrine surrounded by several trees, standing miraculously undamaged in the middle of a vast sea of mud left by the tsunami. ${ }^{80} \mathrm{He}$ points out the significance of local shrines acting as ancient landmarks of safe haven during tsunami and stresses the importance of transmitting the memory of disasters to descendants as part of disaster prevention measures. ${ }^{81}$ The example Imamura draws on is Namiwake shrine (浪分神社), the name of which suggests a place where 'waves are divided (i.e. stopped)'. Local legend is that the god of the sea appeared on a white horse at the time of the Joggan tsunami $(860 \mathrm{AD})$ and controlled the surging wave by dividing it to the north and the south. Imamura's research team's analysis of alluvial deposits found data consistent with the legend. The Jogan tsunami stopped just a few hundred meters from the shrine. ${ }^{82}$

A striking illustration showing the significance of shrines as landmarks of the 'tsunami line' was broadcasted by TBS TV soon after the triple disaster (Hödō Tokushū, 21 August 2011). The report was based on the investigation by a local environmental surveyor Kumagai Wataru who became curious about the fact that many shrines withstood the tsunami. Further investigation of an area stretching 30 kilometres to the north from Minamisōma, the area most affected by tsunami, revealed that out of 84 shrines in the area, 67 stood undamaged. These undamaged shrines were almost exactly on the line that showed how far inland the tsunami came. ${ }^{83}$

79 ibid., 161.

80 Imamura Fumihiko, 'Miyagiken Sendaishi Wakabayashiku engan shūhen' [The Coastal Area of Wakabayashi Ward in Sendai City, Miyagi Prefecture: Photo Image], Gakujutsu no dōkō [Academic Trends] July 2012 (2012).

81 Imamura Fumihiko, 'Daishinsai no jittai to kyōkun no seiri ni mukete' [Facts About the Great Earthquake and Lessons to Be Learned], Presentation at Higashinihon Daishinsai Shakai Shihon Saisei Fukkō Shinpojium [Northeast Japan Disaster Symposium for Social Capital Reconstruction and Recovery] (Miyagi Prefectural Office, 2012).

82 Takase Hiroshi, Yoshida Kazushi, and Kumagai Wataru, Jinja wa keikoku suru [The Warning from Shrines] (Tokyo: Kōdansha, 2012), 76.

83 ibid., 38. 
They were all small 'village shrines' (sonsha 村社), many nameless and no more than tiny wooden structures, that had been cherished and cared for by local people for hundreds of years. Data available from the Association

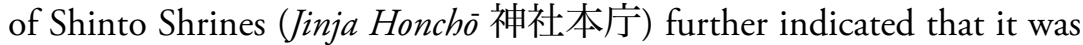
the old shrines that tended to survive the 2011 tsunami. Of 100 shrines in the disaster region that were listed in the imperial survey of Shinto shrines compiled in $927 \mathrm{AD}$ (meaning they are more than 1,000 years old), only three were damaged by the 2011 tsunami. A public relations officer of the association hypothesises that the Jogan tsunami of $860 \mathrm{AD}$ influenced the location of these ancient shrines ${ }^{84}$ Research on the Jogan tsunami deposit has revealed that the frontline of the area inundated by the tsunami more than 1,000 years ago is almost exactly the same as that in $2011 .{ }^{85}$

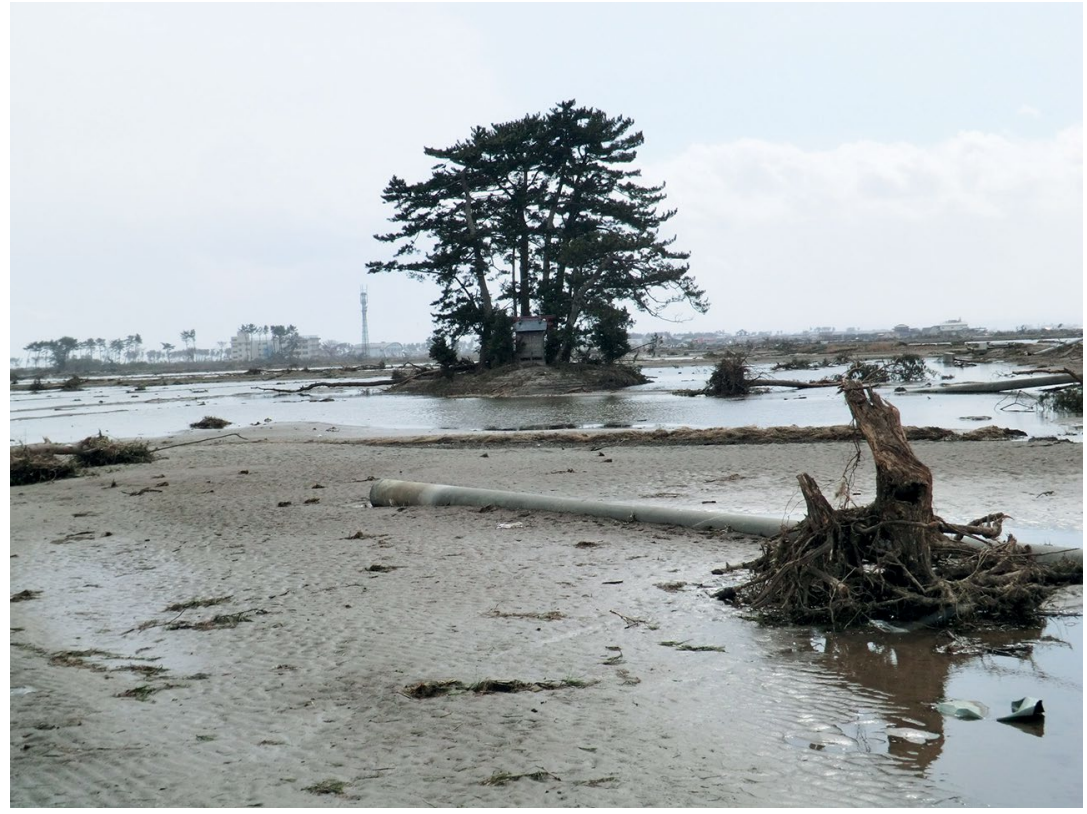

Figure 5: A small village shrine stands intact in the area completely devastated by the tsunami including the tide-water control forest. The coastal area of Wakabayashi Ward in Sendai City, Miyagi Prefecture.

Source: Courtesy of Professor Imamura Fumihiko, Director, International Research Institute of Disaster Science (IRIDeS), Tohoku University. 
It is not yet clear whether the small shrines located on the tsunami line were built to mark the safe haven, or if they are there because they survived the devastation of the tsunami over 1,000 years ago. Either way, what is significant here is the meaning people find in this line of surviving shrines. This is clearly expressed in the words of the mayor of Sōma, a city also devastated by the tsunami. In his own neighbourhood many people survived by escaping to a local shrine that was believed by the locals to enshrine 'the god of tsunami'. Many ran to the shrine following the teaching of their ancestors: 'tsunamis come up to the shrine, and if you reach the shrine you are saved'. The mayor describes the shrine as a monument of past tsunami experience and says it is there to transmit knowledge to descendants: 'I felt most grateful to the ancestors' ${ }^{86}$

As with the case of the local folk festival, the significance of this post-3.11 experience lies in the sense of being connected with the past, by realising anew the significance of the old, often small and nameless shrines, while at the same time feeling the sense of care of ancestors. It is possible that in the disaster-stricken areas where much was lost, quite paradoxically, people found a deeper sense of connectedness with the past. Shrines can at times be associated with state Shintoism, but in this context, the political dimension is hardly relevant. Rather, the meaning of shrines as a symbol of folk religion and local community comes across strongly. And as was the case with the tradition reflected in the notion of 'sansen somoku shikkai jöbutsu' in Buddhism, Shinto as the most ancient spiritual heritage of Japan is also deeply animistic. The (re)discovery of the significance of shrines in the aftermath of the 3.11 disaster is all about the nexus between nature (tsunami), life (of the living) and souls of the dead (people and all other forms of life that once existed), and in that sense it strongly represents the animistic essence of Shinto as folk religion.

In the recovery effort after the triple disaster, another significance of shrines was reappreciated, and provided theory and practice for a project that aims to protect future generations. Shrines have provided a foundation for the project, which now constitutes a new trend of civil society Japan. It is the appreciation of the trees surrounding shrines, the sacred forests, or chinju-no-mori. 
Chinju-no-mori Project: A project to create a green seawall along the coast of the tsunami-affected region began soon after the disaster. It is called the Chinju-no-mori (Sacred Forest 鎮守の森) Project. ${ }^{87}$ It is a grand-scale project that aims to create a 20 to 25 -metre-high, and $300-\mathrm{km}$-long seawall, which is likened to the Great Wall in China. It is a combination of public works, to create the 5-metre-high mound using a gigantic amount of tsunami debris that is otherwise hard to dispose of, and volunteer work, to plant local trees on top of the mound. This organic seawall is expected to grow up to 20 metres high to provide a flexible, robust and beautiful, low-maintenance and sustainable buffer to mitigate tsunami impact and to prevent people and objects from being washed away into the sea.

The project consists of independent subprojects led by different administrations, such as prefectural governments, the Forestry Agency, and the Ministry of Land, Infrastructure, Transport and Tourism, all of which are in charge of the public works to prepare the mound. The volunteer work on the other hand includes gathering local seeds and nuts, preparing seedlings, planting them, and removing weeds. Between 2012 and 2016, a total of 38,451 people participated in the project as volunteers, collecting local seeds and nuts, and nurturing and planting 336,200 trees. $^{88}$

The impetus for the project comes from ecologist Miyawaki Akira (宮脇 昭), Emeritus Professor at Yokohama National University, who has devoted his life to the tree-planting movements around the world. He is the vicepresident of the Chinju-no-mori Project, a public interest incorporated foundation (公益財団法人), presided over by former prime minister Hosokawa Morihiro. It is an umbrella organisation that arranges tree planting, after receiving requests from governments, corporations and citizens' groups. Miyawaki received the 2015 Gotō Shinpei Award, following Ishimure Michiko's award in 2014.

Miyawaki had always stressed the importance of a forest having a mixture of native trees indigenous to the area, especially evergreen broadleaf trees such as castanopsis, machilus and oak. The impact of the tsunami confirmed his theory to a much greater extent than he originally

87 The name of the project was changed from 'Great Forest Wall Project' to 'Chinju-no-mori Project' in June 2016.

88 'Chinju-no-mori Project', morinoproject.com. Accessed 19 June 2016. 
anticipated. He witnessed that the native machilus (Japanese bay trees) not only survived the tsunami but were able to regenerate and regrow. In clear contrast, mono-culture forests of non-indigenous trees such as the pine forest along the coast of Minamisanriku were not only destroyed completely by the tsunami, but the severed trunks became projectiles that harmed people and damaged buildings. The non-indigenous forests failed to stop people being washed away into the sea, and were also unable to regenerate. ${ }^{89}$

Miyawaki calls forests that consist of a mixture of indigenous evergreen broadleaf trees inochi no mori (forests of life 命の森). He argues that these forests preserve DNA specific to the local area, cultivate the sensitivity, creativeness and intelligence of local people, help to stimulate the local economy, and collectively contribute to a sustainable global ecology. He also argues that these forests tend to survive natural disasters (such as earthquake, typhoon, fire, tsunami) and live for thousands of years because they are anchored around a group of tall trees whose roots go deep into the ground. These anchor trees are surrounded by multiple layers of trees of varying heights, which in turn are surrounded by shrubs and grasses. ${ }^{90}$ Miyawaki empahsises that the prototype of the 'forest of life' is the chinju-no-mori, the sacred grove that surrounds shrines, consisting of a mixture of broadleaf evergreen trees and shrubs indigenous to the local area. As he remarks, the sense of sacredness is also significant as it prevents trees from being cut down. ${ }^{91}$

Just as shrines were built to protect their ancestors from tsunamis, people are building forest seawalls, using the knowledge gained from the sacred groves surrounding a shrine. This movement is the complete opposite of the national government's project to build a gigantic concrete seawall along the coast of the Tohoku region. Many people feel that a concrete seawall is an imposition of a huge, costly construction project that cuts the connectedness between people and nature (especially those who work at sea). Concrete seawalls become old and weak with time whereas forest seawalls grow bigger and stronger. Forest seawalls reconnect people with nature and protect them for generations to come. It is possible

89 Miyawaki Akira, Gareki o ikasu 'mori no böhatei' ga inochi o mamoru [Forest Seawall Built on Debris Protects Life] (Tokyo: Gakken Shinsho, 2011); Miyawaki, Akira, 'The Japanese and Chinjuno-mori: Tsunami-Protecting Forest after the Great East Japan Earthquake 2011', Phytocoenologia, 44, issue 3-4 (2014): 235-44.

90 Miyawaki, Gareki, 33-4.

91 ibid. 
that the project represents a new phase of civil society Japan where administration, citizens and cultural heritage are all connected to the theme of protecting life.

Anthropologist John Clammer points out that the celebration of local festivals distinguishes folk Shinto from the more institutionalised state and sect Shinto. ${ }^{92}$ This is a significant remark as 'shrine' or localised folk Shinto played a pivotal role in all the previously discussed post-3.11 recovery efforts: local folk festivals belong to folk Shinto; most of the shrines on the tsunami frontline were small ancient shrines; and sacred groves represent the ecology of folk Shinto as indicated by the anti-shrineconsolidation protests by Japan's first ecologist, Minakata Kumagusu, at the end of Meiji period. Clammer holds that before the late 19th century when a more institutionalised form of Shinto was introduced with the aim of promoting nationalism, Shinto was better understood as 'an ecology'. Folk Shinto provided a way, after 3.11, for people to reconnect with each other (through the folk festivals), to connect with ancestors (by becoming aware of the significance of ancient shrines as tsunami markers) and to form a connection with their descendants (by constructing the great forest seawall using the seeds from, and knowledge of, the sacred forests surrounding folk shrines). The key words used here are exactly the same as the descriptors of the ecology of folk shrines: 'local', 'small', 'diverse' and 'grassroots'. Clammer claims that folk Shinto is nothing but a sophisticated example of animism. ${ }^{93}$

According to Clammer, animism in shrine Shinto comes with radical epistemological implications arising from a permeable sense of humannature boundaries, which allows 'the positive forces that exist on the other side of the boundary ... [to] pass through into the human realm'. ${ }^{94}$ The sense of wonder encapsulated in all three examples seems to suggest, in Clammer's words, the 'permeable sense of human-nature boundaries': the Deer Dance costume being found in the tsunami mud and debris, the string of 67 small ancient shrines on the tsunami line, and the miraculous survival of local machilus trees, species that constitute sacred groves. This sense of wonder was felt not only by locals but also by visiting specialists: the folklorist Akasaka, the tsunami engineer Imamura, and the ecologist

92 John Clammer, 'The Politics of Animism', in John Clammer, Sylvie Poirier, and Eric Schwimmer eds, Figured World: Ontological Obstacles in Intercultural Relations (Toronto: University of Toronto Press, 2004), 90.

93 ibid., 102.

94 ibid., 93. 
Miyawaki. So, do these examples suggest the presence of helpful forces that can pass through into the human realm as explained by Clammer? We do not have the answer to this question, but these episodes are strong examples of radical epistemology that animism can bring about to empower people confronted with socioenvironmental disaster.

\section{Animism as Grassroots Response for a New Modernity}

Clammer points out that animism is 'still widely used [in Japan] as a way of explaining the distinctiveness of the national culture and as a vehicle for constructing a model of Japanese society' ${ }^{95}$ Indeed, the polytheistic/ pantheistic world of Shinto that accommodates an infinite number of kami (deity/god/spirit) as natural life-forces within objects or places can be understood as classical animism. The Buddhist notion of 'sansen sömoku shikkai jöbutsu', which preaches that the Buddha resides not only in humans but in all things, living and dead, animate and inanimate, can also be regarded as classical animism. The availability of this cultural heritage was a precondition of Ogata's philosophy of the life-world, Ishimure's literature, and the Ishimure Michiko phenomenon, as well as the grassroots responses to the triple disaster as discussed above.

The contention of this chapter, however, is that the significance of animism has actually gone beyond that of cultural heritage. I argue that animism (re)emerged as a grassroots response to socioenvironmental crises in increasingly 'postmodern' (i.e. post-materialist) Japanese society, and that this has two significant political and epistemological implications.

Firstly, in political terms, one undeniable characteristic of the discourse on animism in Japan is that it has been part of what Morris-Suzuki calls 'econationalism', a strong intellectual current that locates nature at the core of Japan's national identity. ${ }^{96}$ Recently, animism has been used to criticise monotheist cultures, saying that Japan's tradition can fix environmental problems and bring about a sustainable future, ${ }^{97}$ i.e. a new version of eco-nationalist inspired Nihonjinron (theories about the Japanese). In this

95 ibid.

96 Tessa Morris-Suzuki, Re-Inventing Japan: Time, Space, Nation (New York: M.E. Sharpe, 1998).

97 Yasuda Yoshinori, Isshinkyō no yami: Animizumu no fukken [The Darkness of Monotheism: Revival of Animism] (Tokyo: Chikuma Shobō, 2006). 
chapter, animism has been located clearly at the other side of the political spectrum: a 'worm's-eye level' rather than a 'bird's-eye level'. This has enabled us to discuss animism sociologically, as a grassroots response to the political economy of Japan and, more broadly, to modernity itself. Animism has been presented not as a question of ontology in an ethnographic context, but as grassroots discourse of survival. As pointed out earlier, Ogata's philosophy of life-world is nothing but a postmodern version of animism, and so is Ishimure's literature, which has catered for the emotional and spiritual needs of Japanese society today.

In an article titled 'The Politics of Animism', Clammer goes one step further and argues:

animism has profound political implications [since] it contains a model of human-nature relationships beyond the sociological categories of the state; it is extremely difficult to codify or to convert into any easily administrable theological system; and when it is linked with expressions such as shamanism it can become subversive, a form of power residing in implicit knowledge, a counter-discourse ... and indeed a way of undermining the categories of conventional science. ${ }^{98}$

As Clammer asserts, the increasing significance of ecological, feminist, and New Age thinking in effecting intellectual currents suggests that such ideas, long current in Japan, are, despite their no doubt very different sources, becoming more and more widely diffused'..$^{99}$ The rise of the field of study called post-humanism is an indication of the perceived need to completely reconsider the human-nature relationship. Clammer's insight suggests that animism that (re)emerged in Japan as a citizens' discourse of survival has the political power to appropriate 'cultural heritage' to present a view of 'the new world from below', and that this has even broader potential to accommodate the needs of a world that is painfully aware of the contradictions and limitations of modernity.

This leads us to the second significance of animism that emerged from the grassroots quest for survival in Japan. That is, it can help us address the question of soul in social science and beyond. In the field of social science, the question of the soul constitutes a big lacuna. This is because social science itself is the product of modernity, and secularism has been its most fundamental premise. Matters regarding the soul therefore have

98 Clammer, 'Politics', 84.

99 ibid. 
been epistemologically strange in the social sciences. As a consequence, animism was treated for a long time as if it were magic, and its elimination was considered key to modernity. At the same time, notions of nature and life have been quite limited in the social sciences. Is it possible for the discourse on animism that emerged from Minamata and Fukushima (or post-3.11 Japan) to fill this lacuna and provide a new/old kind of principle of environmental ethics?

Animism is not unique to Japan. Its primordial-indigenous tradition merged with Daoism from China and is now the basis of the strong cultural heritage of East Asia and beyond. Ogata's philosophy can be considered as a late modern and grassroots version of this cultural heritage and thus has the potential to provide environmental ethics that have wide relevance in Asia. If, as the German Ethics Commission for a Safe Energy Supply points out, environmental ethics should be drawn from a spiritual tradition, animistic culture might be as appropriate in the East as Christian tradition and European culture is in the West.

The World Risk Society occurs in the second/late/liquid modernity where the connection between the individual and social institutions weakens. The sociological observations presented in this chapter suggest that after the two environmental catastrophes of Minamata and Fukushima, ${ }^{100}$ many people in Japan have come to learn to connect with each other in a new (yet, at the same time, old) way, and that a sense of animism plays an important part in this. Animism was there to make connections between different entities: the living and the dead, the past and the future, ancestors and descendants, the local area and nature, humans and animals, people, both in, and outside the community. In her 1999 seminal article titled 'Animism Revisited', Bird-David argued that animism represents relational epistemology in contrast to modernist epistemology, ${ }^{101}$ which then stimulated a renewed interest in animism—often referred to as

100 To be precise, the three examples discussed as post-3.11 searches for survival have been drawn from areas, devastated by the earthquake and tsunami, which are north of Fukushima. In Fukushima where the nuclear crisis is current, it is likely to take decades, as was the case of Minamata, for any local discourse to emerge that goes beyond the present legacy of kizuna (bonds). However, given the very nature of the devastation - the total and direct threat to all connectedness of life, the ecosystem and community - it is likely that the vision of the life-world (or animism) will emerge from Fukushima with an even sharper focus on the themes of life, nature and the soul.

101 Nurit Bird-David, “Animism” Revisited', Current Anthropology 40, no. Supplement February (1999). 
New Animism. ${ }^{102}$ This new study of animism fits very well with the understanding of animism that emerged as a grassroots response to the socioenvironmental disaster in Japan.

The search for survival in post-Minamata and post-Fukushima Japan suggests that achieving a sustainable future may demand an epistemological change in social sciences, so that we can revise concepts such as animism, as well as the concepts of soul, life and nature, in a new light. This means including the unseen in the realm of social sciences. It may sound radical, but perhaps there really is nothing new in this. After all, sociology did not exist before Durkheim established the existence of social phenomena sui generis that are independent of the actions and intentions of individuals. Would it be going too far to say that recognition of the existence sui generis of 'the life-world', the world of animism, where soul, nature and life are all connected, might be the pre-condition for a new modernity where sustainable development is possible? 
This text is taken from New Worlds from Below: Informal life politics and grassroots action in twenty-first-century Northeast Asia, edited by Tessa Morris-Suzuki and Eun Jeong Soh, published 2017 by ANU Press, The Australian National University, Canberra, Australia. 